\title{
THE APPLICATIONS OF INTEGRATED PERFORMANCE MANAGEMENT SYSTEMS TO IDENTIFY THE COMPANY'S PERFORMANCE AGAINST INTERNAL TARGETS AND COMPETITIVE BUSINESS ENVIRONMENT: A CASE STUDY IN PT. LEN RAILWAY SYSTEM
}

\author{
Fachry Hasan a, Prof. Dermawan Wibisono ${ }^{b}$ \\ ab Institute Technology of Bandung, Bandung, West Java, Indonesia \\ Corresponding email: fachry.hasan@sbm-itb.ac.id
}

\begin{abstract}
This paper focuses on how the contractor and integrator companies of railway systems could measure their corporate performance and, in the future, the contractor and integrator companies of railway systems could develop their own integrated performance measurement system to improve their company performance and their project service. The best practice from the performance measurement literature is to be compared with practices in the railway industry. Most of the indicators used to control and improve company internal process management today are lagging indicators that measure results. It is, therefore, a need to develop more leading indicators that measure the processes that influence company performance. The measurement system should be extended to measure effects of company's performance and to measure management processes that increase the focus on quality of service and product reliability.
\end{abstract}

Keywords: Integrated Performance Management Systems, IPMS, Integrator Companies in Railways Systems Industries.

\section{Introduction}

Republic of Indonesia ranked fourth with its population of 258,316,051 Number of people (around 258 million inhabitants), or approximately $3.5 \%$ of the total World Population (http://www.bps.go.id/linkTabelStatis/view/id/1274). As a result, a large number of people in Indonesia requires a means of transport and transport infrastructure that is able to accommodate the needs of population mobility in Indonesia.

Currently, Indonesia's transportation systems and infrastructures are dominated by road-based modes of transportation. The imbalance of transport infrastructure development in the past in Indonesia in particular modes of road with railway mode at this point has led to very complicated problems. It was partly due to an imbalance between the growths of road infrastructure with the number of vehicles produced in Indonesia, as well as population growth occuring very rapidly.

Speak about population growth in a country certainly strongly associated with increasing levels of mobility made by a resident in the country, which will also impact the growth rate of the country's economy.

Linkages between population growth, availability of road infrastructure and economic growth in a country would go well as long as no imbalance between these three factors. Due to some fundamental reasons, such as the extremely sectoral nature of national transportation policies 
and the lack of a long term vision, the national road network bears the brunt of the movement of passenger and freight across the country.

In more economically advanced regions such as Java and Sumatera, the road network accounts for over 90 percent of the movement of mining, industrial, plantation and agricultural products to domestic and international ports, either for domestic consumption or for the export market. In both of these regions, as well as in Kalimantan, Sulawesi, and other regions, the road network has experienced excessive pressure due to the increasingly large volume of heavy vehicles with high axle loadings. Progressive road condition deterioration has also been caused by various factors including natural disasters, inundation, landslides, and earthquakes.

Excessive overloading, way beyond the standard axle load of 8-10 tons, has compounded the negative impacts on the endurance and service life of roads, causing deterioration much earlier than their design life. Consequently, Road User Costs (RUCs) have increased exponentially from time to time, mainly caused by increased travel time, worsening congestion, increasingly inefficient use of fuel, increased vehicle damage and other unexpected travel costs. Congested and damaged road networks have led to higher economic costs, diminished competitiveness and suppressed economic growth and distribution.

Increased situation of Road User Costs (RUCs) is eventually being recognized by the government of the Republic of Indonesia, so starting in the year of 2000, the Ministry of Transport began to allocate and does a lot of research related to alternative modes of transport such as rail transport mode.

These researches produce a blueprint of Future Indonesian railway concept. It opens a lot of new business opportunities in developing railway systems in Indonesia. Start from Railways Consultant Company, Railways Contractor Company, event Railways Systems Integrator Company.

PT. Len Railways Systems is a Railways System Integrator Company. This company was established based on market demand of local companies engaged in the railway system.

Beginning of ability in terms of Systems Integration and modification of signaling which was once the legacy signaling from European Countries, PT. Len Railways Systems successfully developed its own signaling system in the country such as the signaling system electromechanical (Electro Mechanical Interlocking/EMI, signaling electrical (PLC Based Interlocking) and signaling-based computer (computer based Interlocking/CBI) had certificates from both home and abroad.

Through the cooperation with overseas companies that are experienced in their field, PT. Len Railways Systems also carry out business concepts with technology transfer and Transfer Manufacturing, in order to obtain products of signaling which are qualified, such as Automatic Train Protection (ATP), which helps increase the factor of safety trip train fire up the Computer Based train Control (CBTC), which is an advanced signaling system to regulate the unmanned train journey (Driver less operation).

With the opening of a business opportunity in the field of railway system in Indonesia, PT. Len Railway Systems can take advantage of this opportunity to the fullest if PT. Len Railway Systems can run the company well. To be able to achieve all, PT. Len Railway Systems must perform the 
measurement of company performance. PT. Len Railway Systems is already using Kriteria Penilaian Kinerja Unggul (KPKU) in order to identify their corporate performance.

KPKU is performance measurement systems based on combination of Malcolm Baldrige method and some traditional measurement, which the measurement system is tend to report past performance (lagging metrics).

In this journal, the researcher develops new corporate performance management systems using Integrated Performance Management Systems as the framework.

\section{Literature Review}

Performance measurement system was originally defined by Ljungberg (1994) as an order of measurement based on specific rules and procedures to include, compile, represent and communicate data in a key combination that reflects the performance and characteristics of the selected process is quite effective that allows the analysis of the intellectual as an alloy to take the necessary action.

Performance measurement is "the process of quantifying the efficiency and effectiveness of past actions" (Neely, 2000), while the other concept defines as "the process of evaluating how well organizations are managed and the value they deliver for customers and other stakeholders" (Moullin 2001). Discussion on the relative merits of these definitions appeared in several articles in the newsletter of the Performance Management Association.

Performance and performance measurements are concepts developed from the terms productivity and productivity measurement. It was first used in the manufacturing industry to measure the relationship between input and output. Today, more sophisticated methods and systems have been developed and performance measurement is more and more used as a tool in the improvement work in all sorts of businesses (Andersen and Fagerhaug, 2002). Although performance measurement has developed, it is still being criticized from many holds. Kaplan and Norton (1996) say that the measurement system for businesses historically has been financial, and for many companies, it still is. Another challenge is that it is often difficult to see results of improved quality in the companies' measurement system (Kaplan, 1990).

Even though Neely et al. (1995) say that "Performance measurement is a topic often discussed but rarely defined", there are several different definitions of performance measurement. One reason for this can be that the purpose and use of performance measurement varies. Bourne et al. (2003) claim that if the definition is too precise it doesn't convey what is now being labeled in the literature and in practice as "performance measurement". They therefore use the less precise definition: "performance measurement is the use of a multi-dimensional set of performance measures for the planning and management of businesses".

The basic purpose of performance measurement is to provide feedback from the work that is performed. This feedback is important in order to control the systems, processes and activities that are measured, but even more important to be used as a tool in the improvement work. Fagerhaug (1999) says that "you cannot manage what you cannot measure, what gets measured gets done, and measurements influence behavior". Kaplan and Norton (1996) say that companies must use measurement systems if they want to survive and prosper in the information age competition. Lynch and Cross (1991) state: "The purpose of performance measurement is then to motivate behavior leading to continuous improvement of customer 
satisfaction, flexibility and productivity". Bredrup (1995) lists a number of specific purposes for performance measurement and concludes that a common denominator is improvement.

Andersen and Fagerhaug (2002) say that performance measurement is necessary for decision making and they suggest that the Performance Management Systems should become the instrument panel or cockpit for this purpose. In addition, they point at several other reasons why companies should measure performance: as an early warning system, to alter behavior, to implement strategy and policy, to monitor trends, to prioritize improvements, to evaluate improvement projects, as a marketing tool, as an input to bonus and incentive systems, as a basis for benchmarking and to increase motivation. Bititci et al. (2004) provide evidence that consistent use of performance measurement alter management behaviors and organizational culture.

The most famous framework is probably the balanced scorecard (BSC) developed by Kaplan and Norton (1996). The BSC is a framework for integrating measures derived from strategy. The intention with the scorecard is to develop a balanced set of measures. It is based on the thought that the drivers for future financial performance are customers' satisfaction, internal processes and learning and growth in the organization. The authors claim that a good balanced scorecard should have an appropriate mix of outcome measures (lagging indicators) and performance drivers (leading indicators) (Kaplan and Norton, 1996).

The most recent framework and is the most suitable framework used in Indonesia is probably the Integrated Performance Management Systems (IPMS) developed by Prof. Dermawan Wibisono (2003). Like the BSC, the IPMS is a framework for integrating measures derived from strategy. The difference between BSC and IPMS is Non-Financial measurement.

To design a Performance Management System, you first have to decide what the system should be based on. Kaplan and Norton (1996) say this should be the vision and strategy of the organization, which is supported by Lynch and Cross (1991). Andersen and Fagerhaug (2002) and Bititci et al. (1997 and 2000) argue that the PMS also should be based on the stakeholders' needs. All the authors listed emphasize that it is important to improve, and thereby measure, the processes to achieve good results. To ensure the validity of the PMS used, it should be regularly reviewed and updated. This means that targets, measures and sets of measures are regularly reviewed to ensure that they remain valid (Bititci and Nudurupati, 2002a).

In order to develop performance indicators, there are many aspects that have to be considered. A fundamental rule is that the set of measures should be balanced and multi dimensional. Kaplan and Norton (1996) state that the measures should view organizational performance from four perspectives: financial and customer (external measures), and internal business processes and learning and growth (internal measures). The logic is a chain with cause and effect relationships, where you find the financial perspective on the top and the learning and growth perspective at the bottom. All the measures are therefore linked together. The authors claim that if you do not work with the learning and growth perspective you will not improve your internal processes, which will lead to unsatisfied customers that at the end will results in lower financial performance. Andersen and Fagerhaug (2002) list some typical types of performance measures: "hard" vs. "soft", financial vs. non-financial, result vs. process, result vs. diagnostic vs. competence, efficiency vs. effectiveness vs. changeability in addition to cost, time, quality and flexibility. 
It is obvious that a company will not succeed only by developing a "perfect" measurement system. The PMS is just one part of the total management system, which consist of several other important factors. According to Andersen and Fagerhaug (2002), a general management system can be seen as a system with three different modes or levels: strategic planning, day-today management and improvement. Performance measurement is only one of the tools that could be used to manage these modes. Other tools could be: Organisational self-assessment, benchmarking, BPR, supply chain management and TQM. The challenge is to combine these tools in a best possible way to improve the business processes.

\section{Methodology}

The methodology used in this paper is based on survey, literature review, discussion, and interview with the key personnel (top management). This paper analyses the KPI of one Contractor and Railway Systems Integrator Company (subsidiary of a state-owned-enterprise) in Indonesia using the Integrated Performance Management Systems (IPMS) as a performance tool for determining the company's strategy to improved their performance.

The data used for the analysis obtained from the company's the annual report. The annual report also provides the company's vision and mission. Thus, the first step in this paper is to analyze the vision and mission of the company. Afterwards, analysis of the Integrated Performance Management Systems is conducted based on existing company's data. The Integrated Performance Management Systems resulted in a company's strategy to enhance the company performance.

Based on the survey, discussion and interview with key persons, the researcher define that the company conduct performance management system with Kriteria Penilaian Kinerja Unggul (KPKU)framework based on Malcolm Baldrige. The researcher found the barrier from the performance measurement applied that the strategy not linked to the departmental, team, individual and organizational goals.

\section{Analysis}

To analyzed the key performance indicators of the company, the researcher should identify vision, mission, and corporate strategic of the company. The steps used are composed of the following (Quezada et al., 2009):

\section{Definition of vision and mission}

In this step, the company establishes the organizational identity (vision) and where it wants to go (mission).

Company Vision:

"Becoming the most reliable world class company for cost effective, innovativerailway systems and light rail turnkey electro-mechanical systemsby using empowered employees"

Company Mission:

"To contribute in improving people productivity and mobility through delivering the reliable and safe railways systems". 


\section{Identification of strategic themes}

Identification of strategic themes provides vertical links through the five dimensions of the Integrated Performance Management Systems, seeing the strategy as a parallel and complimentary theme (Kaplan \&Norton, 2006).

\section{> Definition of general objectives}

In PT. Len Railway Systems' company mission is stated to participate in people's mobility and productivity by providing reliable and zero accident railways systems.PT. Len Railway Systems established in order to answer the needs of stakeholders railway and road transport modes rail against railway systems (signaling systems, telecommunications systems, electrical systems, etc.) that are reliable and safe, in order to support efforts to increase the productivity of railway transport facilities and infrastructure. A world class company means that PT. Len Railway Systems will not only serve the national market of Indonesia, but also regional and international markets.

To meet the requirement of a company's Vision and Mission as the core value to identified KPI of the company, PT. Len Railway Systems should identify the business strategy by identify:

$>$ Internal and External Analysis

> In internal analysis there are several factors that should be identified to know internal company's ability to face business challenges, such as:
1. Resource
2. Capabilities
3. Core Competencies
4. Strategic Competitiveness

In external analysis, there are also several factors that should be identified to know and understand company's opportunity and threat, such as:
1. Economic Factor
2. Socio-cultural Factor
3. Global Factor
4. Technological Factor
5. Political/Legal Factor
6. Demographic Factor

\section{KPI Analysis}

Using data of survey, literature and discussion with key persons, the researcher can identified the perspectives of Integrated Performances Management Systems. 
Financial

\begin{tabular}{|l|c|c|c|}
\hline \multicolumn{1}{|c|}{ KPI Perspectives } & Target & Realisasi 2014 & Realisasi 2015 \\
\hline Revenue Growth & $100 \%$ & $-79.25 \%$ & $-99.49 \%$ \\
\hline Ebitda Margin & $100 \%$ & $65.24 \%$ & $69.67 \%$ \\
\hline Growth of Personnel Cost & $100 \%$ & $73.98 \%$ & $76.75 \%$ \\
\hline Account Receivable & $100 \%$ & $92.04 \%$ & $85.31 \%$ \\
\hline Non Government Market Portofolio & $100 \%$ & $21.86 \%$ & $22.28 \%$ \\
\hline
\end{tabular}

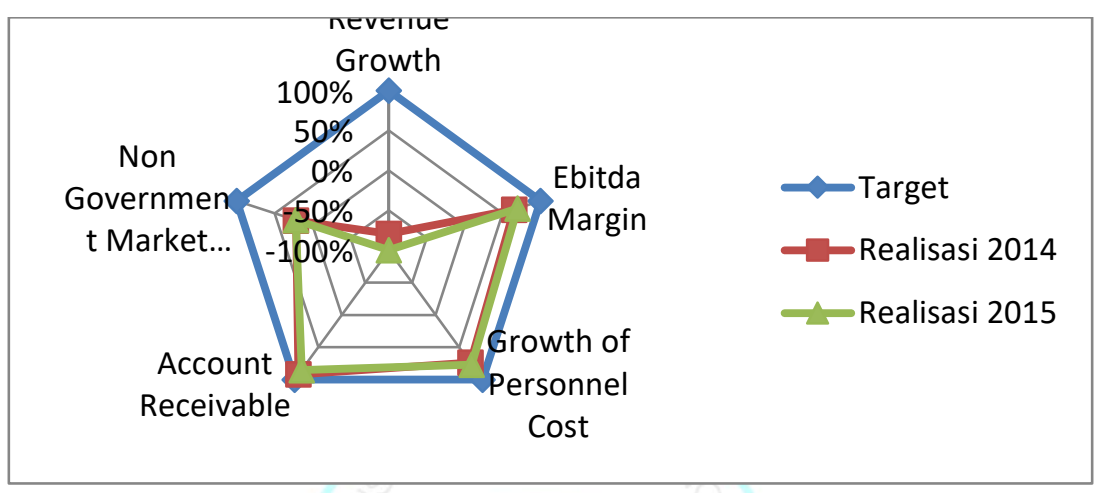

Non-Financial

\begin{tabular}{|l|c|c|c|}
\hline \multicolumn{1}{|c|}{ KPI Perspectives } & Target & Realisasi 2014 & Realisasi 2015 \\
\hline Customer Loyalty & $100 \%$ & $63 \%$ & $123 \%$ \\
\hline Customer Satisfaction & $100 \%$ & $100 \%$ & $100 \%$ \\
\hline New Customer & $100 \%$ & $0 \%$ & $100 \%$ \\
\hline Strategic Alliance & $100 \%$ & $0 \%$ & $300 \%$ \\
\hline
\end{tabular}

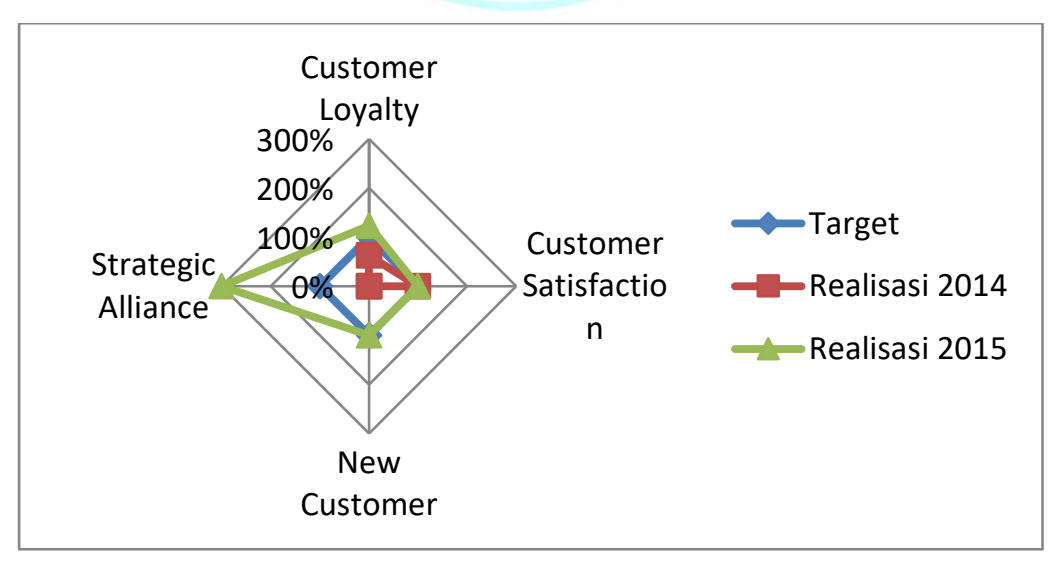

Asia Pacific Institute of Advanced Research (APIAR) 
Asia Pacific Journal of Advanced Business and Social Studies

ISBN (eBook): 9780994365675 । ISSN : 2205-6033

Year: 2017 , Volume: 3, Issue: 2

A P I A R

Internal Process

\begin{tabular}{|l|c|c|c|}
\hline \multicolumn{1}{|c|}{ KPI Perspectives } & Target & Realisasi 2014 & Realisasi 2015 \\
\hline Operational Process & $100.00 \%$ & $100.00 \%$ & $100.00 \%$ \\
\hline Innovation & $100 \%$ & $50 \%$ & $200 \%$ \\
\hline Realization of Investment & $100 \%$ & $46.98 \%$ & $72.35 \%$ \\
\hline Physical Realization of Investments & $100 \%$ & $56.67 \%$ & $113.33 \%$ \\
\hline After Sales & $100 \%$ & $131.40 \%$ & $177.40 \%$ \\
\hline
\end{tabular}

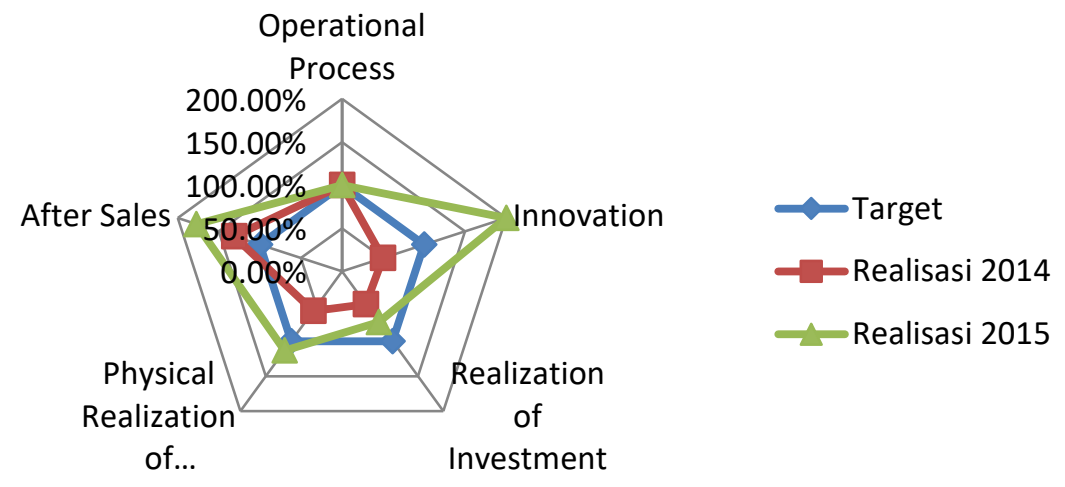

Human Capital

\begin{tabular}{|l|c|c|c|}
\hline \multicolumn{1}{|c|}{ KPI Perspectives } & Target & Realisasi 2014 & Realisasi 2015 \\
\hline Work Safety & $100 \%$ & $0 \%$ & $100 \%$ \\
\hline Employee Engagement & $100 \%$ & $52.82 \%$ & $92.52 \%$ \\
\hline Employee Competance & $100 \%$ & $80 \%$ & $100 \%$ \\
\hline
\end{tabular}

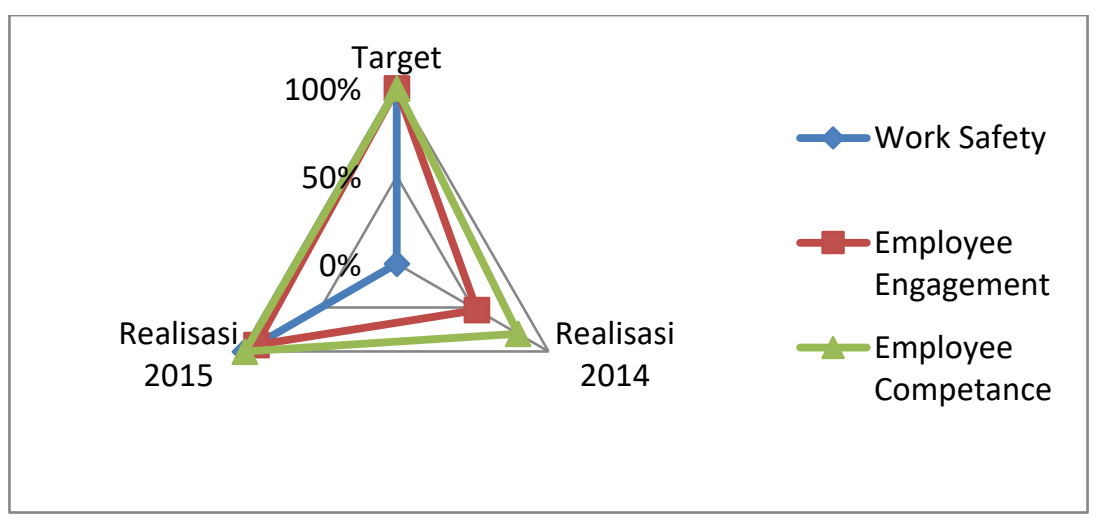

Asia Pacific Institute of Advanced Research (APIAR)

DOI: 10.25275/apjabssv3i2bus6 


\section{Organization}

\begin{tabular}{|l|c|c|c|}
\hline \multicolumn{1}{|c|}{ KPI Perspectives } & Target & Realisasi 2014 & Realisasi 2015 \\
\hline Follow-up the Findings of the External & $100 \%$ & $23 \%$ & $46 \%$ \\
\hline Project Risk Review & $100 \%$ & $50.21 \%$ & $95.40 \%$ \\
\hline Management Report Submission & $100 \%$ & $100 \%$ & $140 \%$ \\
\hline Governance and Leadership of the Company & $100 \%$ & $82.44 \%$ & $102.96 \%$ \\
\hline
\end{tabular}

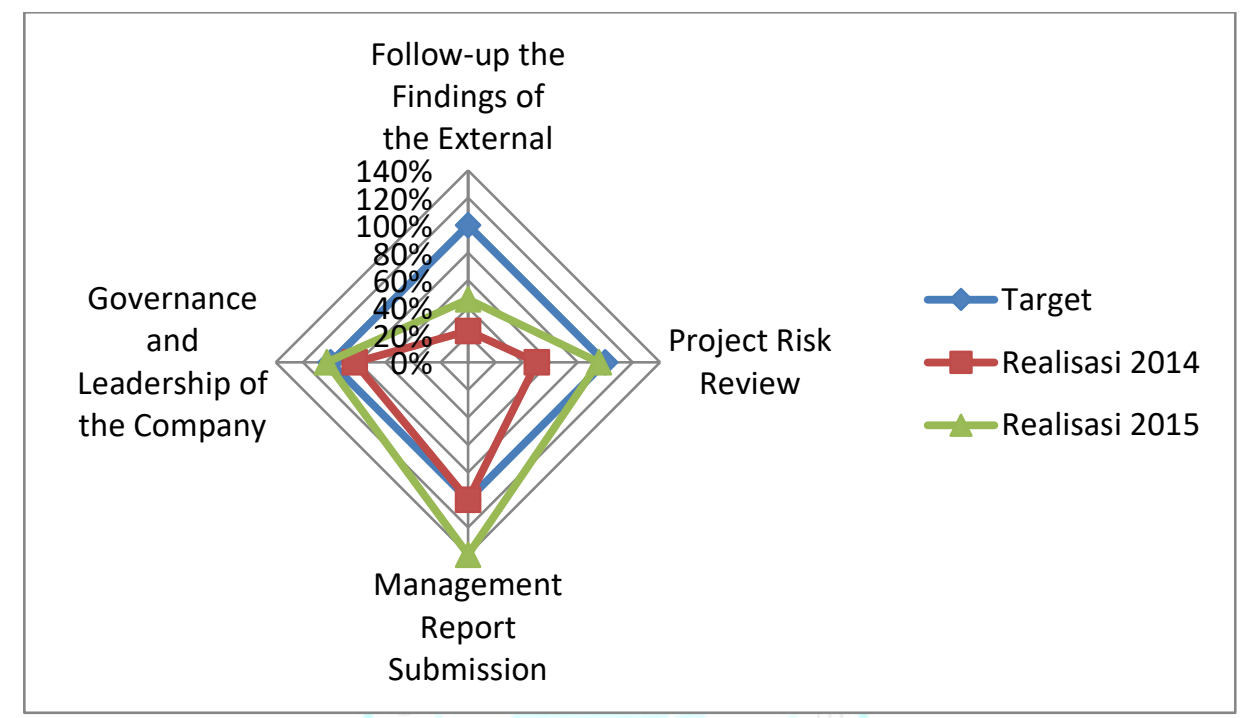

Total of perspective can be seen below

\begin{tabular}{|l|c|c|c|}
\hline \multicolumn{1}{|c|}{ KPI Perspectives } & Target & Realization 2014 & Realization 2015 \\
\hline Revenue Growth & $100 \%$ & $-79.25 \%$ & $-99.49 \%$ \\
\hline Ebitda Margin & $100 \%$ & $65.24 \%$ & $69.67 \%$ \\
\hline Growth of Personnel Cost & $100 \%$ & $73.98 \%$ & $76.75 \%$ \\
\hline Account Receivable & $100 \%$ & $92.04 \%$ & $85.31 \%$ \\
\hline Non Government Market Portofolio & $100 \%$ & $21.86 \%$ & $22.28 \%$ \\
\hline Customer Loyalty & $100 \%$ & $63 \%$ & $123 \%$ \\
\hline Customer Satisfaction & $100 \%$ & $100 \%$ & $100 \%$ \\
\hline New Customer & $100 \%$ & $0 \%$ & $100 \%$ \\
\hline Strategic Alliance & $100 \%$ & $0 \%$ & $300 \%$ \\
\hline Operational Process & $100 \%$ & $100.00 \%$ & $100.00 \%$ \\
\hline Innovation & $100 \%$ & $50 \%$ & $200 \%$ \\
\hline Realization of Investment & $100 \%$ & $46.98 \%$ & $72.35 \%$ \\
\hline Physical Realization of Investments & $100 \%$ & $56.67 \%$ & $113.33 \%$ \\
\hline After Sales & $100 \%$ & $131.40 \%$ & $177.40 \%$ \\
\hline Work Safety & $100 \%$ & $0 \%$ & $100 \%$ \\
\hline Employee Engagement & $100 \%$ & $52.82 \%$ & $92.52 \%$ \\
\hline Employee Competance & $100 \%$ & $80 \%$ & $100 \%$ \\
\hline Follow-up the Findings of the External & $100 \%$ & $23 \%$ & $46 \%$ \\
\hline Project Risk Review & $100 \%$ & $50.21 \%$ & $95.40 \%$ \\
\hline Management Report Submission & $100 \%$ & $100 \%$ & $140 \%$ \\
\hline Governance and Leadership of the Company & $100 \%$ & $82.44 \%$ & $102.96 \%$ \\
\hline
\end{tabular}




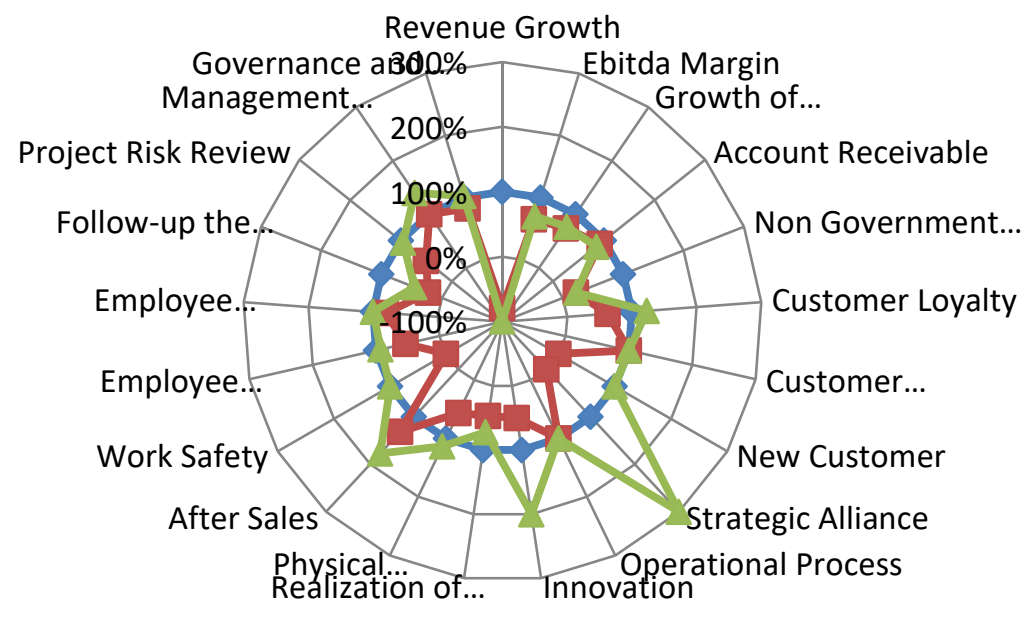

\begin{tabular}{|c|c|c|c|c|c|c|c|}
\hline Perspective KPI & Weighted & Score & $\begin{array}{c}\text { Score Based on } \\
\text { Max Weight }\end{array}$ & Target & 2014 & 2015 & Status \\
\hline \multicolumn{8}{|l|}{ Financial } \\
\hline \begin{tabular}{l|l} 
Revenue Growth \\
\end{tabular} & 7.5 & (6.3950) & $(6.3950)$ & $>16 \%$ & $55.79 \%$ & $50.13 \%$ & Below Target; Down performance \\
\hline Ebitda Margin & 10 & 7.5411 & 7.5411 & $>9 \%$ & $5.87 \%$ & $6.27 \%$ & Below Target; Up performance \\
\hline Growth of Personnel Cost & 5 & 2.3391 & 2.3391 & $<8 \%$ & $5.92 \%$ & $6.14 \%$ & Below Target; Up performance \\
\hline Account Receivable & 5 & 18.7249 & 5.0000 & $<10 \%$ & $17.96 \%$ & $24.69 \%$ & Below Target; Down performance \\
\hline Cash from Operating Activities & 5 & 5.0000 & 5.0000 & Positif & Positif & Positif & meets Target \\
\hline Non Government Market Portofolio & 7.5 & 2.0798 & 2.0798 & $>7 \%$ & $1.53 \%$ & $1.56 \%$ & Below Target; Up performance \\
\hline \multicolumn{8}{|l|}{ Non- Financial } \\
\hline \begin{tabular}{|l|l|} 
& Customer Loyalty \\
\end{tabular} & 5 & 6.2821 & 5.0000 & $>78 \%$ & $48.78 \%$ & $96.25 \%$ & meets Target \\
\hline Customer Satisfaction (Number of Compalint) & 2.5 & 2.5000 & 2.5000 & $\begin{array}{c}\text { Max } 3 \\
\text { times/Project }\end{array}$ & 0 & 0 & meets Target \\
\hline New Customer & 2.5 & 2.5000 & 2.5000 & $>=1$ & 0 & 1 & meets Target \\
\hline Strategic Alliance & 2.5 & 2.5000 & 2.5000 & $>=1$ & 0 & 3 & meets Target \\
\hline \multicolumn{8}{|l|}{ Internal Process } \\
\hline \begin{tabular}{|l|l|} 
& Operational Process \\
\end{tabular} & 5 & - & - & $<2 \%$ & $0 \%$ & $0 \%$ & meets Target \\
\hline Innovation & 5 & 10.0000 & 5.0000 & $>2$ Unit & 1 & 4 & meets Target \\
\hline realization of investment & 5 & 1.3500 & 1.3500 & $100 \%$ & $46.98 \%$ & $72.35 \%$ & Below Target; Up performance \\
\hline physical realization of investments & 2.5 & 3.3333 & 2.5000 & $>75 \%$ & $42.50 \%$ & $85.00 \%$ & meets Target \\
\hline After Sales & 2.5 & 7.0009 & 2.5000 & $>25 \%$ & $32.85 \%$ & $44.35 \%$ & meets Target \\
\hline \multicolumn{8}{|l|}{ Human Capital } \\
\hline \begin{tabular}{l|l} 
Work Safety \\
\end{tabular} & 5 & - & - & $<1$ & 1 & 0 & meets Target \\
\hline Employee Engagement & 5 & 5.0705 & 5.0000 & $>75 \%$ & $39.62 \%$ & $69.39 \%$ & Below Target; Up performance \\
\hline Employee Competance & 5 & 5.0000 & 5.0000 & $>5$ & 4 & 5 & Below Target; Up performance \\
\hline \multicolumn{8}{|l|}{ Organization } \\
\hline follow-up the findings of the external & 2.5 & 2.5000 & 2.5000 & $100 \%$ & $23 \%$ & $46 \%$ & Below Target; Up performance \\
\hline Project Risk Review & 4 & 4.4999 & 4.0000 & $>80 \%$ & $40.17 \%$ & $76.32 \%$ & Below Target; Up performance \\
\hline management report submission & 3 & 3.0000 & 3.0000 & $<1$ Week & 7 & 5 & meets Target \\
\hline governance and leadership of the company & 3 & 1.4998 & 1.4998 & $>50 \%$ & $41.22 \%$ & $51.48 \%$ & meets Target \\
\hline & 100 & 86.3265 & 60.4149 & & & & \\
\hline
\end{tabular}




\section{Conclusions}

This paper improves the knowledge about the importance of using the Integrated Performance Management Systems in the company as a strategy to improve work performance, supported by analysis of the vision and mission as a reference for the company's activities for the next few years. The Vision for this company has been correlated with each section perspective of the company, such as financial, Non-Financial, Internal Processes, and Resources Avaibility. As for the mission, PT. Len Railway Systems has been using the Kriteria Penilaian Kinerja Unggul (KPKU) in designing corporate mission. The vision and mission of the company is already adjusted to be matched with the Integrated Performance Management Systems that have met the critical perspective to the company. Relations of the vision, mission and Key Performance Indicators against Integrated Performance Management Systems perspective are generating strategic initiatives for each perspective. After analysis, it a strategic initiative was found as output. This means that companies that already have the Integrated Performance Management Systems Key Performance Indicators can be used as a tool to gain a strategic initiative for companies, especially companies state-owned enterprises.

In this paper, using Integrated Performance Management Systems analysis for contractor and Railway Systems Integration company, but for further research Integrated Performance Management Systems can be used for any other company. Integrated Performance Management Systems can also be used for companies that already know their Key Performance Indicators or companies that have not set Key Performance Indicators. 


\section{References}

i. Wibisono, D. (2016) "How To Create World Class Company - Panduan Bagi Direktur dan Manager”, Penerbit ITB, Bandung, Jawa Barat, pp 1-312.

ii. Hafnika, F., Hamdani, O., Simbolon, R. J. and Wibisono, D. (2016) "Strategy Map Formulation for Designing Strategic Plan In Indonesia Transportation Organization", Asia Pacific Institute of Advanced Research, Vol. 2, Issue. 2, pp. 103-112.

iii. $\quad$ Adhiprasangga, A., Sari, A. P., Putra, T. W. and Wibisono, D. (2016) "Develop Balanced Scorecard From KPI In Construction Companies (Case Study: State-Owned Enterprise)", Asia Pacific Institute of Advanced Research, Vol. 2, Issue. 2, pp. 156-166.

iv. Andersen, B. and Fagerhaug, T. (2002). "Performance Measurement explained - designing and implementing your state-of the art system”, ASQ Quality Press, Milwaukee, Wisconsin, pp. 1-109.

v. Bititci U.S., Turner T. and Begemann C, (2000). "Dynamics of Performance Measurement Systems", International Journal of Operations and Production Management, Vol. 20, no. 6, pp 692704.

vi. $\quad$ Bititci, U.; McCallum, N., Bourne, M. and Turner, T. (2002b), "Performance indicators for sustainable competitive advantage: the next frontier". Performance Measurement 2nd international workshop, Hanover, 6-7 June 2002

vii. Bititci US, Mendibil M, Nudurupati S, Turner T and Garengo P. (2004). "The interplay between performance measurement, organizational culture and management styles" Measuring Business Excellence, 1 March 2004, Vol. 8, No. 3, pp. 28-41.

viii. Bourne, M., Nelly, A., Mills J. and Platts K. (2003). "Implementing performance measurement systems: a literature review" International Journal of Business Performance Management”, Vol. 5, No. 1, pp. 1-24.

ix. Bredrup, H. (1996). "Performance Measurement in a Changing Competitive Industrial Environment: Breaking the Financial Paradigm", Doctor dissertation, Norwegian University of Science and Technology (NTNU), Department of Production and Quality Engineering, Trondheim, Norway, pp. 36-65.

x. Fagerhaug, T. (1999). "A new Improvement Oriented Method and Model for Self-Assessment for Business Excellence”, Doctor dissertation, Norwegian University of Science and Technology NTNU, Department of Production and Quality Engineering, Trondheim, Norway, pp. 41-47.

xi. Kaplan, R. S. and Norton, D. P. (1996). “The Balanced Scorecard - translating strategy into action”, Harvard Business School Press, Boston, Massachusetts, pp. 1-189.

xii. Kaplan, R. S. (1990). "Limitations of Cost Accounting in Advanced Manufacturing Environments" In: (Kaplan, R. S. and Johnson, T. (Ed.)) "Measures for Manufacturing Excellence", Chapter 1, Harvard Business School Press, Boston, Massachusetts

xiii. Kennerley, M. and Neely A., (2000). "Performance Measurement Frameworks - A Review", 2nd International Conference on Performance Measurement, Cambridge, 19-21 July 2000.

xiv. $\quad$ Neely, A.D., Mills, J.F., Gregory, M.J. and Patts, K.W. (1995), "Performance measurement system design - a literature review and research agenda", International Journal of Operations and Production Management, Vol. 15, No. 4, pp. 80-116

xv. Neely, A.D. (2000) "Performance Measurement: Past, Present and Future", Centre for business Performance, Cranfield School of Management. 